International Journal of Linguistics, Literature and Culture
Available online at https://sloap.org/journals/index.php/ijllc/
Vol. 5, No.1, January 2019, pages: 62-67
$\begin{aligned} & \text { ISSN: 2455-8028 } \\ & \text { http://dx.doi.org/10.21744/ijllc.v0i0.000 }\end{aligned}$

\title{
Karma on Hinduism Philosophy Perspective
}

Wayan Suryasa $^{\text {a }}$

I Gede Nika Wirawan ${ }^{b}$

\section{Article history:}

Submitted: 09 October 2018

Revised: 18 December 2018

Accepted: 27 January 2019

\section{Keywords:}

dharma;

karma;

moksha;

panca srada;

philosophy;

\begin{abstract}
Hinduism is the oldest religion beginning in India. The development of Hinduism spread to the other parts of Asia, one of them is in Southeast Asia. The development of Hinduism in Indonesian territory is unavoidable because of the trading which was conducted between the kingdoms in Indonesia and other kingdoms in Asia. As we already know that Indonesia is a country that has become one of the places to go travelers who travel on the Silk Road. The Silk Road is a trade route in Asia where it delivers a lot of goods from the kingdoms in China to several kingdoms in Asia and sone of them are the kingdoms in Indonesia and in India. Therefore, we can see the influence of Chinese cultures and Indian cultures that are deeply embedded in Indonesian culture. One of the philosophies of Hinduism that still adheres to the people until today is the philosophy of karma in which Hindus believe that what we do today has an impact on what we will get in the future, it is a reflection of what we have planted in previous lives.
\end{abstract}

2455-8028 ${ }^{\circledR}$ Copyright 2019. The Author. This is an open-access article under the CC BY-SA license (https://creativecommons.org/licenses/by-sa/4.0/) All rights reserved.

\section{Author correspondence:}

Suryasa, W.

ITB STIKOM Bali, Denpasar, Indonesia

Jalan Raya Puputan Renon No. 86, Tel: (0361) 244445

Email address: suryasa@stikom-bali.ac.id

a ITB STIKOM Bali, Denpasar, Indonesia

${ }^{\mathrm{b}}$ ITB STIKOM Bali, Denpasar, Indonesia 


\section{Introduction}

Hinduism as the largest religion in the era of the royal past, which is highly glorified by the ancestors of the Indonesian people, we should preserve its preservation today. This noble cultural heritage of our ancestors should be sacred and preserved until the end of this modern era (Sadlon et al., 2008; Singh \& Bowden, 2006; Sivam, 2005). As for our reasons for preserving Hinduism and the culture of our ancestors, there is no other respect for our ancestors who built Indonesia into a prosperous country in the days of the previous Hindu kingdom. Hindu culture also has a positive impact on Hindus in modern times (Mahapatra et al., 2012; Osen, 1996; Rastogi, 2011). One of the impacts that we see is that the works of art on the Bali Island of the Gods have their own characteristics and appeal compared to other regions. This is inseparable from the strong influence of Hinduism in Bali which is reflected through the traditional arts of the island of Bali that captivate the charm to attract foreign attention. Karma is one of the philosophies in Hinduism that attract much attention these days. What is Karma? Many people confused about what really Karma is. That is why the research regarding the philosophy of Karma is important to be conducted. The description of the formulation of the problem that can be elaborated in accordance with the background of Hinduism above is; What are the meaning of Pala and Punarbhawa karma and their examples?

\section{Results and Discussions}

The Vedas are sacred knowledge, true spiritual knowledge about eternal truths, sacred teachings that originate from the essence of Hindu teachings. The division of the Vedas consists of the Vedic Sruti and the Vedic Smrti. Weda Sruti is a revelation that was revealed directly by God through the sages. The Sruti Veda consists of Regweda, the time of the first revelation to be revealed so it is the oldest Vedas. The Rig Veda contains god's chants consisting of 10,552 mantras and entirely divided into 10 Mandalas. Sama Veda is a collection of mantras and contains teachings about god's songs. Sama Veda consists of 1,875 spells. Yayur Veda is a Vedas consisting of spells that come from Regweda. The total number of spells totaled 1,975. Atharvaveda is a collection of incantations containing magical teachings. Atharvaveda consists of 5987 mantras from Rigveda. Its contents are prayers for daily life such as asking for healing and others. Atharvaveda was compiled by Rsi Sumantu.

One of the philosophies in Veda is Karma. Therefore Hindu people believe in the ideology of karma. We can see the philosophy of karma in one of the chants in Bagawan Gita.

"The phala (effect) caused by millions of different karmas (deeds) performed by a person and determining the conditions of his/her life (as the soul) in the next incarnation, can only be decided correctly, justly and wisely by Sri Krishna in his aspects as paramartha "

(Bhagawan Gita 13.23 and 18.61)

Karma itself is one of the philosophies of Hinduism in which Hinduism believes in Panca Srada, i.e. every Hindu believes in God, believes in karma, believes in the incarnation, and believes in eternal happiness or what is called Moksa. One part of Panca Serada is believing in karma. In Hindu religious literature we can find out the philosophy of karma, one of which is the Bhagavadgita mentioned above.

Karma comes from Sanskrit that is Karma from the vein of the word "Cr" which means to make or do, it can be concluded that karma means deeds or behavior. Meanwhile, Phala which means fruit or yield. Then it can be concluded that the Law of Karma Phala means: A rule or punishment in which it is the result of the action. Then it can be concluded that the Law of Karma Phala means: A rule or punishment of the previous act (Kleisen, 2013; Laurenti, 2016; Lipner, 2004).

In the encyclopedia of Hinduism, karma is explained as traditional philosophy that leads to the Vedas. Indian philosophy often contrasts the Kandala karma to the tradition associated with Jnana Knada (aspects of science). But then, the word karma refers to the law of action. According to this concept, one's actions or karma in his current life will shape their life in the next birth. In addition, in the context of Bagawan Gita, Karma Yoga refers to yoga of actions, regardless of the results of those actions. Mohandas Karamchand Gandhi made the word Karmayoga well

Suryasa, W., \& Wirawan, I. G. N. (2020). Karma on Hinduism philosophy perspective. International Journal of Linguistics, Literature and Culture, 5(1), 62-67. https://doi.org/10.21744/ijllc.v5n1.850 
known as reflected in his political activities. Indian Hindu traditions, Jainism, Buddhism and Sikhism all accept this karmic philosophy.

There are three types of karma, i.e.:

a) Prarabda karma, which is an action done at the present time of life and accepted in the present life as well.

b) Kriyamana karma is an action done now in this world but the results will be received after death in the afterlife.

c) Sancita karma, the deed done now, the results will be obtained at a future birth.

Meanwhile the characteristics of the Law of Karma are:

a) The law of karma is eternal: It means that it has existed since the creation of the universe and is in effect until the universe experiences pralaya (doomsday).

b) The law of karma is universal: It means it applies not only to humans but also to creatures of the entire universe.

c) The law of karma applies from the first era of creation, today, the age to come.

d) The law of karma is very perfect, just, no one can avoid it.

e) The law of karma is no exception to anyone, even for Sri Rama, who is incarnated by Vishnu, does not want to change the existence of the law of karma.

Examples of the daily philosophy of karma itself can be seen that in our lives, if we always do good, karma will always come to us, in the future, there will be others who do good to us. On the other hand, if we do no do good to others or to other creatures, later on, we will get the same thing happening as what we have done before. Karma can occur in this life as well as in the future's life. If we have a good life in the present, maybe our karma is good in the previous life and we should keep our karma in the present life so that in the next life we can reap the rewards of our karma in the present life.

Immanuel Kant (1724 1804) gives his idea of the afterlife theory in which according to his theory that the consequence of our limitation of knowledge rules out virtually all the belief of the existence of God, the immortality of the soul and the freedom of will. Because of that, this principal can become the fundamental philosophy of the people regarding the afterlife. The Hindus people in Bali believe this since this theory is similar to the Vedas teaching in which become the fundamental life of the Balinese to do good in this life so that they can get a better life in the future (Deshpande et al., 2018; Jones \& Ryan, 2006). Meanwhile, Punarbhawa is also one of the five Hindu beliefs in which the five beliefs are known as Panca Srada. In ancient Hindu literature, we can find the philosophy of Purnabawa in one of the chants of the Bhagavadgita.

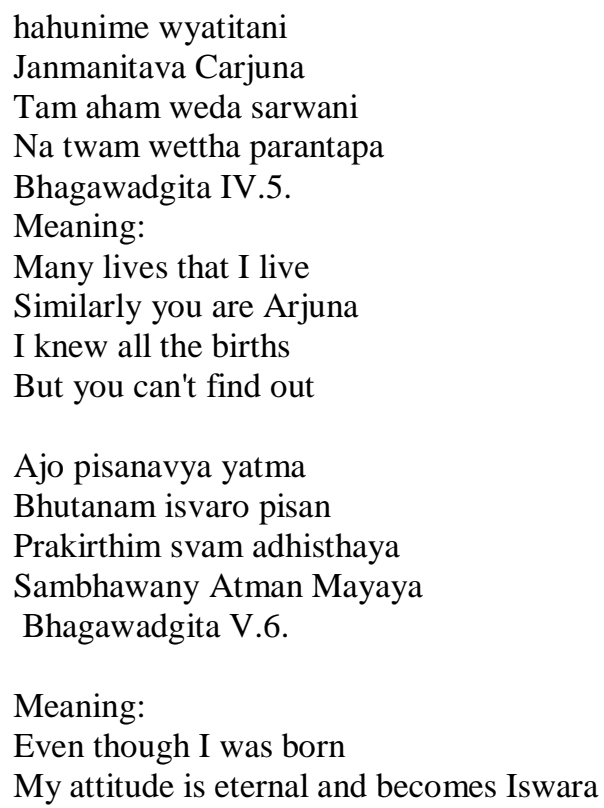


But I hold fast my nature

Come incarnated by cyberspace

Punarbhawa or also called reincarnation in Hindu belief in which they will be reborn in the next life. And they will bring their previous karma. In this caste we can conclude that life at this time will affect our live in the future. Therefore, Balinese always try to do their best in today's life so that they can be born in a better life in the future. Karma has many form in the life of Balinese Hindu. One of the Hindus literature mentioned that:

"Without form, how can we meditate while thinking of God? If God is truly formless, how can our minds be focused? When there is nothing to think about, we will not be able to focus and the mind will hover during meditation, or will go to and fro. Therefore, the wisest thing that can be done is to meditate while thinking of a form, remembering something is an indirect method of thinking of a true god without form. (Vishnu Samhita 29: 55-57)

On its application in religious life, Hindus often use symbols as a means of worship. This has no other meaning than making these symbols as manifestations of God so that they can focus their minds better. With these symbols, religious people can focus their minds more on praying. There are many religious symbols in Hinduism, we can see these symbols in several places of the Hindu holy places and in the implementation of Yadnya (Thomas, 2014; White et al., 2019).

One of the best known Hindu symbols is the Swastika. The Swastika is one of the oldest symbols in the world that existed thousands of years ago. The word Swastika represents the hope that everything is in good condition. In addition, the swastika also represents the symbol of Dharma. There are four kinds of duties that we should do in this life according to this believed to do good Karma. The first Dharma is Dharma Kriya, then Dharma Santosa, and Darmajati. The deeper meaning of this symbol in Hinduism represents Dharma, Kama, Artha, and Moksha.

In addition, a temple also has its own meaning. The temple symbolizes the human body which is the abode of God. God resides in every living soul. The temple symbolizes the holy place or the abode of God on this earth and all the activities in the temple are the centers of the sacredness of God to make good Karma. Other forms of symbols in Hinduism to make good Karma are:

1) Human form with various advantages, such as four, eight and twelve arms, three-legged three-eyed and others, symbolizing Brahma, Vishnu, Siva, Goddess Saraswati, Laksmi, Uma / Parwati / Durgha, Vamana, Rama Parasu, Rama and Krishna.

2) Garuda bird (in Regweda called Garutmat) where this golden casteed bird symbolizes a bird that can fly, giving prosperity to his people. The other form as a dragon Taksaka (in Sivagama in Indonesia) is a form of Sanghyang Siva, who guards the earth in the sky in the form of atmosphere. Anantabhoga is the form of Sanghyang Brahma who embraces the earth's core which endlessly endows food.

3) The form of half-human and half animal symbolizes Lord Gana, son of Siva; Narasinga awatara Vishnu, the human body with a lion head; Hayagriva, human body and horse body.

4) The shape of half the human and half the plant symbolizes the soma tree, the Kha tree (this symbol in Indonesia is almost unknown).

5) The shape of certain objects or letters, symbolizing the sun or discs (wheels), the Sanghyang Surya symbol, the symbolic month of the Goddess Chandra, the Ongkara (Omkara, AUM) symbol of the Almighty God; A (Ang) Brahma symbol, U (Ung) Vishnu symbol; the letter M (Mang) Siva symbol, also certain lines such as Swastika, Tri Kona, square, triangle (star), the circle can be arranged as a yantra which is the symbol of Hyang Widhi Wasa. The symbol of gods in Bali can be found in bebanten.

In doing a good deed in this life the Hindu people must follow the caste system that is made by society. The Caste System is an idealistic hierarchical construction, it is a reflection or expression of Hindu life in order to form a life order. But in reality, there is a very striking difference from what was previously expected. In reality, this system is chaotic, between fit and ideal is something far from fitting the word to be applied, it depends on the time, place and situation. We have a number of clues that in the Dharma text itself that in real life, what is meant by this ideal is still ambiguous.

In contrast to India, the caste system in Bali is still synonymous with Balinese culture. As we know, the Balinese still uphold the Caste system in their society. We can see that every Balinese person has their own characteristics that

Suryasa, W., \& Wirawan, I. G. N. (2020). Karma on Hinduism philosophy perspective. International Journal of Linguistics, Literature and Culture, 5(1), 62-67. https://doi.org/10.21744/ijllc.v5n1.850 
distinguish them from one caste to another. In Bali the Brahmin caste occupies the highest level, then below that there is the knight caste followed by the Vaishya and Sudra castes. This is a growing belief in Balinese society that both knights and Brahmins are highly respected castes in Bali.

In Hindu chronicles, Caturwarna is four classes of life or division of life in a society that is placed in accordance with one's talents, skills, qualities, and mentality in their work. These four classes are then referred to as the caste. The four castes are Brahmins, Ksatriya, Vaishya and Sudra. The caste of the Brahmins is symbolized by the white caste which characterizes people who serve in the field of religious spirituality. The caste of the knight is symbolized in red which characterizes the people who serve in the fields of leadership, preservation and national defense. Vaishya castes symbolized in yellow as their functional group in a society that serves for the welfare of the community in the economic, industrial and others. The caste of the Shudras symbolized in black is a group of people who serve in the field of employment.

\section{Conclusion}

The conclusion that can be drawn from the above explanation is karma is the result or fruit of our life that will have an impact on our next life. If we do good things in this life we will be reincarnated or also called Punarbhawa in the next life and get a good life in the future. Hindu people use symbols to make good Karma in which these symbols have many meanings, in which these symbols will help Hindus to concentrate their thoughts when they pray.

\section{Conflict of interest statement and funding sources}

The authors declared that they have no competing interest.

\section{Statement of authorship}

The authors have a responsibility for the conception and design of the study. The authors have approved the final article.

Acknowledgments

We are grateful to thank the two anonymous reviewers for the earlier version of this article in a prior publication. 


\section{References}

Deshpande, A., Goel, D., \& Khanna, S. (2018). Bad karma or discrimination? Male-female wage gaps among salaried workers in India. World Development, 102, 331-344. https://doi.org/10.1016/j.worlddev.2017.07.012

Jones, C., \& Ryan, J. D. (2006). Encyclopedia of hinduism. Infobase publishing.

Kleisen, L. M. (2013). A positive view on road safety: Can 'car karma'contribute to safe driving styles?. Accident Analysis \& Prevention, 50, 705-712. https://doi.org/10.1016/j.aap.2012.06.022

Laurenti, R. (2016). The karma of products: Exploring the causality of environmental pressure with causal loop diagram and environmental footprint (Doctoral dissertation, KTH Royal Institute of Technology).

Lipner, J. (2004). On Hinduism and Hinduisms: The way of the banyan. In The hindu world (pp. 21-46). Routledge.

Mahapatra, A., Srinivasan, A., Sujithra, R., \& Bhat, R. P. (2012). Management of internal hemorrhoids by Kshara karma: An educational case report. Journal of Ayurveda and integrative medicine, 3(3), 115.

Osen, J. (1996). The communications decency Act and the karma of chaos-Part 1. Network Security, 1996(10), 1319.

Rastogi, S. (2011). Effectiveness, safety, and standard of service delivery: A patient-based survey at a pancha karma therapy unit in a secondary care Ayurvedic hospital. Journal of Ayurveda and integrative medicine, 2(4), 197. https://dx.doi.org/10.4103\%2F0975-9476.90767

Sadlon, E., Sakamoto, Y., Dever, H. J., \& Nickerson, J. V. (2008, January). The karma of Digg: Reciprocity in online social networks. In 2008 Workshop on Information Technologies and Systems, WITS 2008.

Singh, V., \& Bowden, C. L. (2006, January). Bipolar bozukluk, karma dönemlerin tani ve tedavisindeki gelişmeler. In Yeni Symposium (Vol. 44, No. 1, pp. 23-33). University of Istanbul.

Sivam, P. R. (2005) Hiduism For Beginners, Sydney: Simha Publications

Thomas, M. C. (2014). Glycemic exposure, glycemic control, and metabolic karma in diabetic complications. Advances in chronic kidney disease, 21(3), 311-317. https://doi.org/10.1053/j.ackd.2014.03.004

White, C. J., Kelly, J. M., Shariff, A. F., \& Norenzayan, A. (2019). Supernatural norm enforcement: Thinking about karma and God reduces selfishness among believers. Journal of Experimental Social Psychology, 84, 103797. https://doi.org/10.1016/j.jesp.2019.03.008

\section{Biography of Authors}

\begin{tabular}{l} 
Dr. I Wayan Suryasa, SS., MHum. is a senior lecturer in ITB STIKOM Bali, Denpasar, \\
Indonesia. He graduated bachelor degree in Warmadewa University and completed a \\
master and doctoral degree in Udayana University. He is as well as an editor in Scopus \\
journal and has been published some papers in the Scopus database. He is currently \\
managing editor for some journals in SLOAP, LingCuRe, and ScienceScholar. He \\
became a member of HPI since 2013 to present and to be a mentor in Publon in Web of \\
Science. His online profile is also available at Sinta, Orchid and Google Scholar. \\
Email: suryasa@stikom-bali.ac.id / iwayansuryasa @ utm.edu.ec / \\
iwayansuryasa@gmail.com \\
$\begin{array}{l}\text { I Gede Nika Wirawan, S.S., M.Hum., M.H. is an English lecturer in ITB STIKOM } \\
\text { BALI-INDONESIA. He graduated from the Department of English Language and } \\
\text { Literature, University of Udayana (2010), Master Degree of Translation Study in } \\
\text { University of Udayana (2012), and Master Degree of Law from the University of } \\
\text { Mahendradatta (2019). Besides teaching English, he also teaches in Konsultan Bahasa } \\
\text { as an Indonesian Language Teacher for foreigners in Bali. In addition, he is also a } \\
\text { certified translator to translate legal documents from Indonesian to English and vice } \\
\text { versa, as well as from French to Indonesian, French to English and vice versa. } \\
\text { Email: nika.wirawan@ gmail.com }\end{array}$ \\
\hline
\end{tabular}

Suryasa, W., \& Wirawan, I. G. N. (2020). Karma on Hinduism philosophy perspective. International Journal of Linguistics, Literature and Culture, 5(1), 62-67. https://doi.org/10.21744/ijllc.v5n1.850 